\title{
Thalassia as a Food Source: Importance and Potential in the Marine and Terrestrial Environments ${ }^{1}$
}

\author{
V. P. Vicente, J. A. Arroyo-Aguilú, and J. A. Rivera ${ }^{2}$
}

\begin{abstract}
The chemical composition of Thalassia leaves is described. Of the leaf-dry matter, $40.6 \%$ consists of soluble nutrients: crude protein, lipids, soluble carbohydrates and ash. Crude protein content was $17 \%(R=15.8-18.1 \%)$. Essential nutritive minerals were found in considerable quantities: calcium, $1.32 \%(R=1.21-1.47 \%)$; phosphorus, $.21 \%(R=.19-.23 \%)$; potassium, $3.0 \%(R=2.47 \%-3.30 \%)$ and magnesium, $1.26 \%(R=1.09 \%-1.38 \%)$. The cell wall or neutral-detergent fiber fraction was $59.4 \%(R=46.1-64.6 \%)$, of which $19.1 \%$ consisted of hemicellulose. The lignin content varied from $22.9 \%\left(\mathrm{KMnO}_{4}\right)$ to $9.1 \%\left(\mathrm{H}_{2} \mathrm{SO}_{4}\right)$ depending on whether $\mathrm{KMnO}_{4}$ or $\mathrm{H}_{2} \mathrm{SO}_{4}$ was used as an oxidizing agent. The importance of Thalassia leaves as a food source for the seagrass community is described by five major food chains hereby proposed: the large herbivore, the fish herbivore, the gastropod herbivore, the urchin herbivore and the detrital food chains. The potential value of Thalassia as a food source for domestic animals is evaluated on the basis of comparison with forage crops.
\end{abstract}

\section{INTRODUCTION}

On a global basis, seagrasses $(32,46)$ constitute one of the most common coastal ecosystem types. Turtle grass (Thalassia testudinum) is the dominant seagrass in the upper sublittoral zone of the Caribbean (15). One of the many important roles of Thalassia in the ecology of tropical and subtropical shallow marine environments is that it forms extensive meadows, which serve as mating, spawning, nursery, breeding and habitat grounds for numerous species, including those of commercial value to man, such as fishes, shrimps, lobsters, and molluscs (16, 20, 21, 23, 29, 34, $37,40)$.

Several herbivores that use Thalassia leaves as a primary source of food are in turn fished commercially: the green turtle (Chelonia mydas) (22, 24), the manatee (Trichechus manatus) (40), fishes $(40,41)$, the queen conch (Strombus gigas) $(7,39,40)$, and the sea urchins (Tripneustes esculentus and Lytechinus variegatus) $(1,31)$ (table 1).

'Manuscript submitted to Editorial Board May 31, 1978.

${ }^{2}$ Senior Associate, Marine Ecology Division, Center for Energy and Environment Research, University of Puerto Rico, Mayagüez, P. R.; Nutritionist, Animal Industry Department, Agriculture Experiment Station, Mayagüez Campus, University of Puerto Rico, Río Piedras, P. R.; and Research Associate II, Marine Ecology Division, Center for Energy and Environment Research, University of Puerto Rico, Mayagüez, P. R., respectively. The authors wish to express their gratitude to Dr. D. G. St. Louis and to the staff of the Central Analytical Laboratory of the Agricultural Experiment Station for conducting the chemical analyses, and to Dr. J. G. González, Mr. J. Vicente-Chandler, and Ms. T. Ortega for the revision of the manuscript. 
Further, these herbivores are also eaten by natural predators in the ecosystem, forming an array of food chains which, if simplified, could be divided into the following five proposed categories (figs. 1-5): the large herbivore food chain, the fish herbivore food chain, the gastropod herbivore food chain, the urchin herbivore food chain, and the detrital food chain. These five food chain types are based on personal observations and communications, and on data published $(6,7,9,18,21,22,24,25,26$, $28,30,31,32,33,34,38,39,40,41,46$ ).

The food chains could be ramified or diversified further, or divided into sub-food webs or even developed into new ones because there are many variations in the transfer of energy from the primary producers to upper

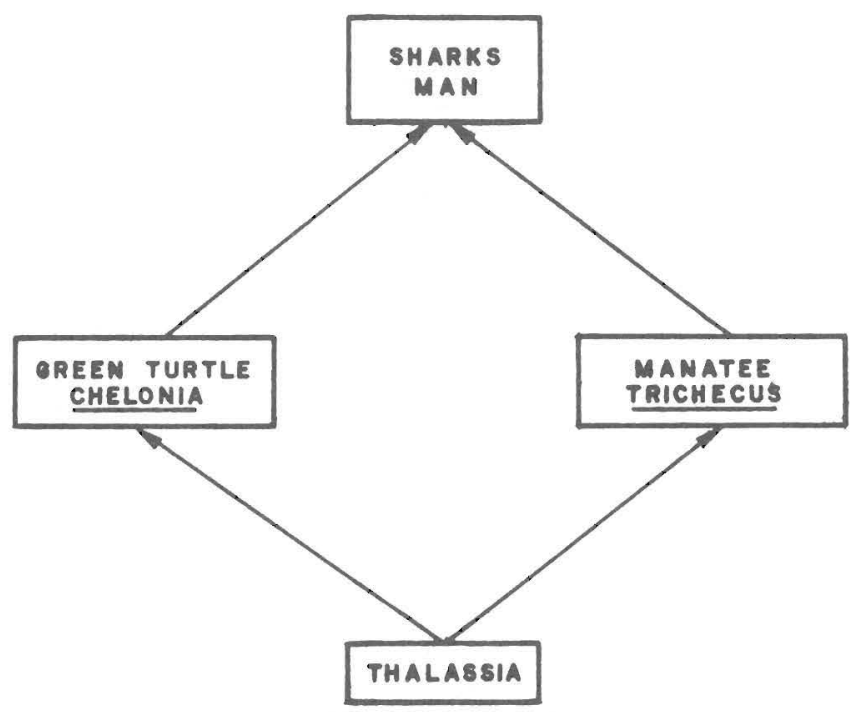

Fig. 1.-Large herbivore food chain.

trophic levels in marine ecological systems. Direct grazing on Thalassia by herbivores is intense in the Caribbean $(10,36,40,51)$, while in temperate and subtropical latitudes direct grazing on seagrasses apparently is insignificant (6). In the latter, it has been postulated that the primary energy in Thalassia enters the system via the detrital pathway (54).

These five elemental food chains show how the chemical nutrients of Thalassia contribute to the sustenance and survival of numerous organisms. It has been shown that these chemicals are transported to other marine biotopes and serve as a source of nutrition $(29,35,36,40)$. These food link diagrams also show how nutrients in Thalassia leaves, or toxic chemicals and pollutants that are picked up by Thalassia, might be 
transferred to, or accumulated by upper trophic levels, including man. Therefore, the chemical composition of Thalassia is of utmost significance, as far as trophic studies are concerned.

\section{MATERLALS AND METHODS}

Thalassia blades were collected at three Thalassia beds in Guayanilla Bay, Puerto Rico (fig. 6), October 1976. Blades were cut off at the base with stainless steel scissors, at a depth of $1 \mathrm{~m}$ at each station. The leaves were placed in polyethylene plastic bags and taken to the laboratory where they were kept frozen for a period of approximately 1 week.

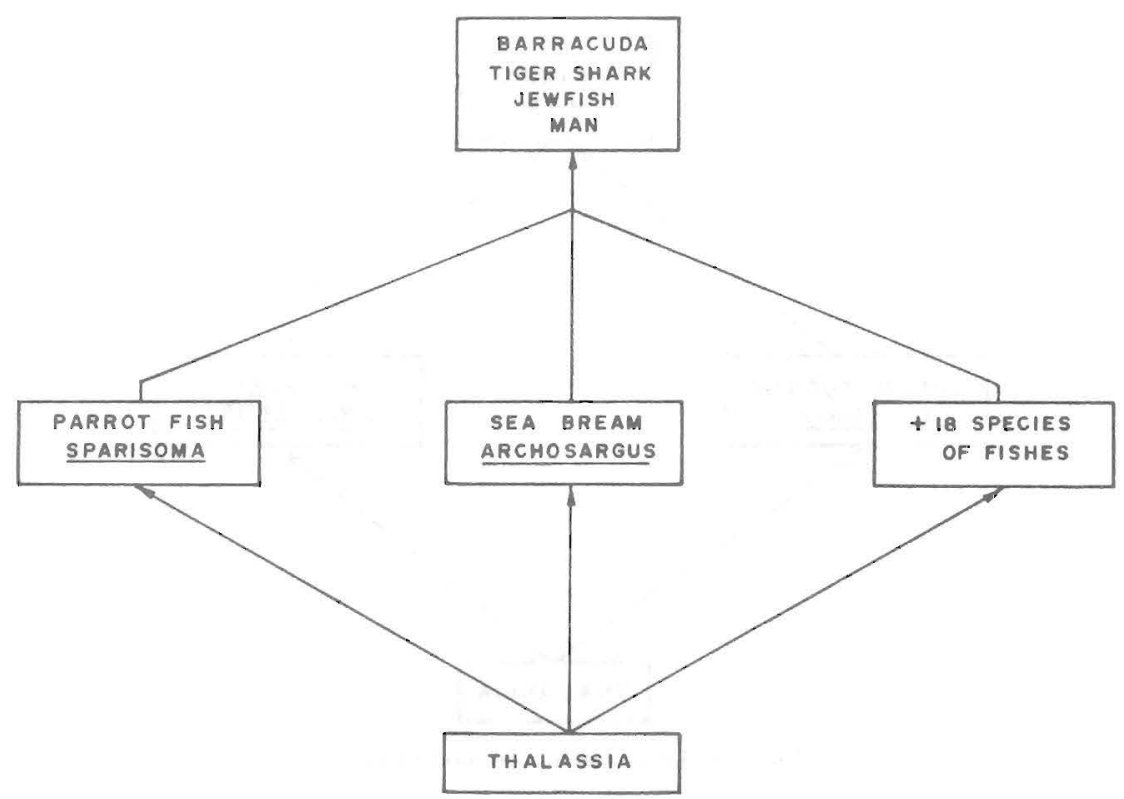

FIG. 2.-Fish herbivore food chain.

Subsequently, the leaves were defrosted with tap water. Newly emerging blades, free of epiphytes, and the epiphyte-free lower section of the adult blades were separated from the samples and laid over high absorbent paper to remove excess water. The leaves were wrapped in absorbent paper and dried in a precision Thelco Oven, Model $17,{ }^{3}$ at $60^{\circ} \mathrm{C}$ to constant dry weight, for approximately $48 \mathrm{hrs}$. Dried samples were ground

${ }^{3}$ Trade names in this publication are used only to provide specific information. Mention of a trade name does not constitute a warranty of equipment or materials by the Agricultural Experiment Station of the University of Puerto Rico, nor is this mention a statement of preference over other equipment or materials. 
in a Wiley mill, passed through a $1 \mathrm{~mm}$ screen and placed in a desiccator.

The leaf material was analyzed for crude protein (CP), cell wall or neutral-detergent fiber (NDF), lignocellulose or acid-detergent fiber $(\mathrm{ADF})$, lignin $(\mathrm{L})$, cellulose $(\mathrm{C})$, silica $(\mathrm{Si})$, calcium $(\mathrm{Ca})$, phosphorus $(\mathrm{P})$, magnesium $(\mathrm{Mg})$ and potassium $(\mathrm{K})$. Cell contents or neutral-detergent solubles (NDS) were calculated as the difference between $100 \%$ and NDF, and hemicellulose $(\mathrm{H})$ as the difference between NDF and ADF. CP was determined by the Kjeldahl method (\% nitrogen $\times 6.25$ ) (4). Ca and $\mathrm{Mg}$ were analyzed according to Greweling (19). P and $\mathrm{K}$ were analyzed

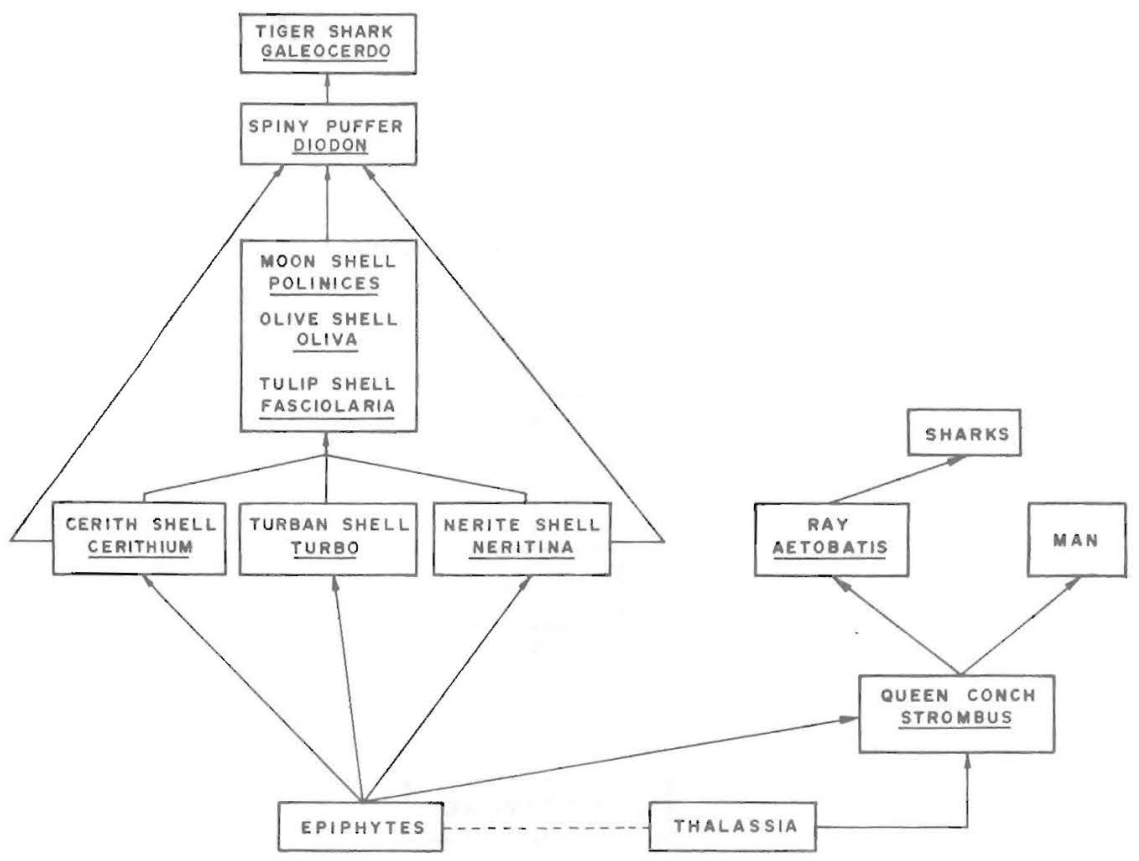

FIG. 3.-Gastropod herbivore food chain.

according to Riera (42). NDF, ADF, L, C and Si were determined by the method of Goering and Van Soest (17).

The fibrous carbohydrate fractions of Thalassia leaves collected in Puerto Rico have been determined in the past as crude fiber (CF) by means of the proximate analysis scheme (9). Failure to separate the carbohydrates into soluble and insoluble, digestible and indigestible fractions is the main criticism against the use of the proximate analysis scheme $(3,12,27)$. Therefore, the more precise Goering and Van Soest (17) techniques were used in this study. With detergents, this method provides a technique in which the NDS fraction can be separated from 


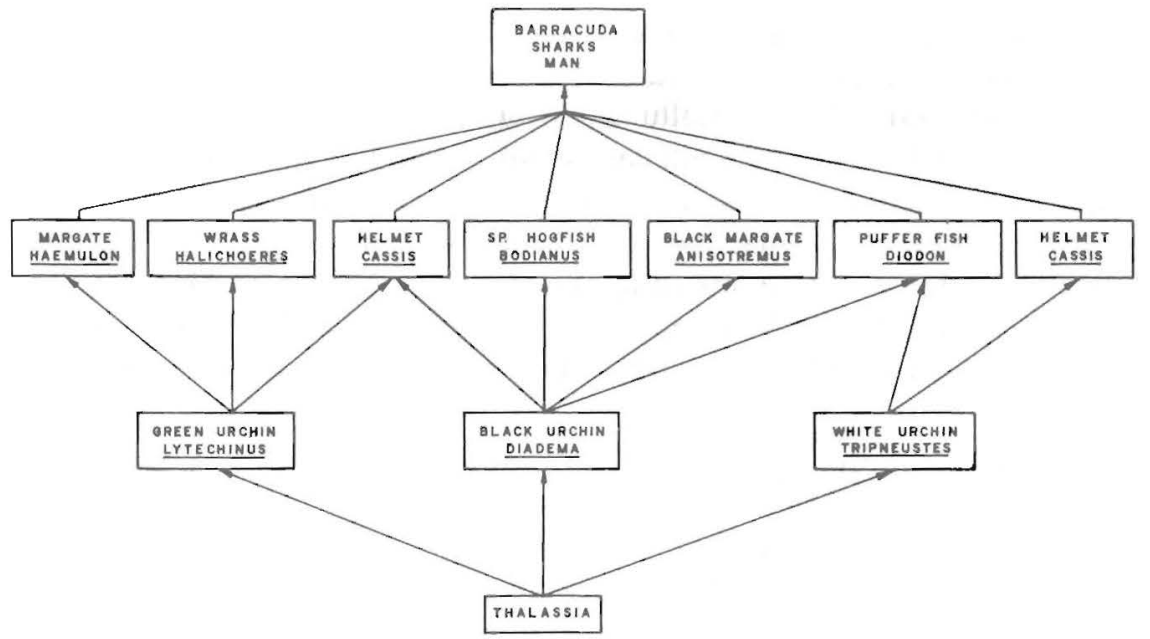

FIG, 4.-Urchin herbivore food chain.

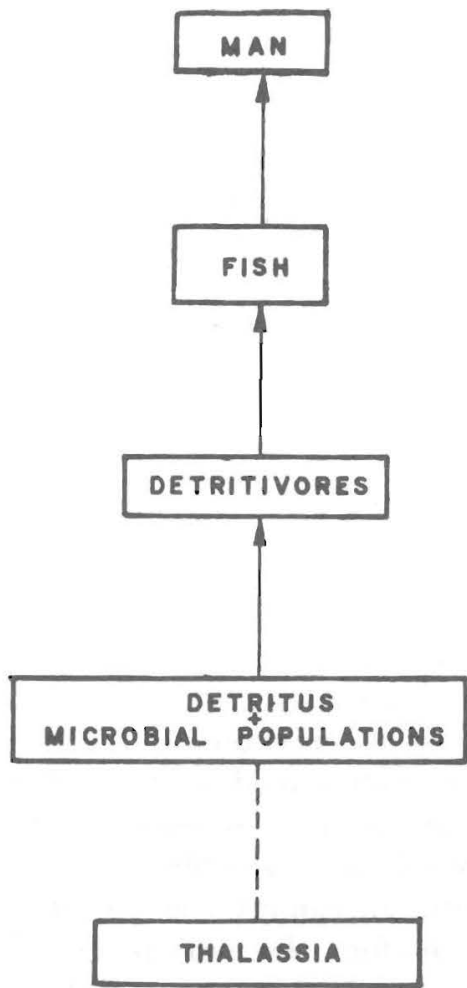

FIG. 5.-Detrital food chain. 
the more fibrous fraction or NDF. The CP, soluble carbohydrates, lipids, and ash are extracted in the NDS fraction while the cell wall components (L, C, H, Si) are extracted in the NDF fraction.

\section{RESULTS AND DISCUSSIONS}

Tables 2 and 3 show the values obtained in this study for the chemical components of Thalassia. Of the total leaf-dry matter, a mean of $59.4 \%$

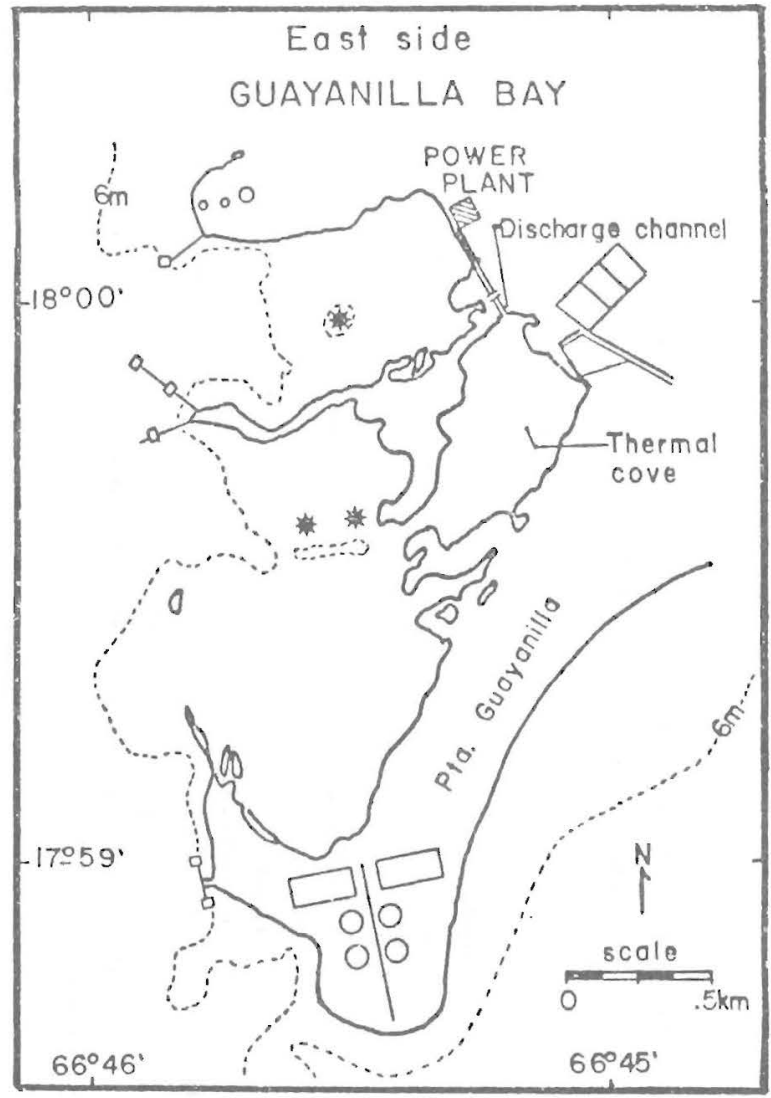

FIG. 6.-Thalassia beds in Guayanilla Bay, Puerto Rico.

$(\mathrm{R}=46.1-64.6 \%, \mathrm{n}=6)$, consisted of NDF. ADF fraction consisted of $40.4 \%(\mathrm{R}=38.8-41.8 \%, \mathrm{n}=6)$ and $\mathrm{H} 19.0 \%$. The value for $\mathrm{L}$ in the ADF fraction varied depending on whether potassium permanganate $\left(\mathrm{KMnO}_{4}\right)$ or sulfuric acid $\left(\mathrm{H}_{2} \mathrm{SO}_{4}\right)$ is used as the oxidizing agent. The cell wall components of Thalassia, when $\mathrm{L}$ is determined by the $\mathrm{H}_{2} \mathrm{SO}_{4}$ method, are generally similar to tropical forage grasses (table 2).

Van Soest and Wine (50) indicated that differences between the $\mathrm{KMnO}_{4}$ 
TABLE 2.-Fibrous carbohydrate fractions of the seagrass Thalassia testudinum as compared to 10 tropical forage grasses

\begin{tabular}{|c|c|c|c|c|c|c|c|c|}
\hline Scientific name & Common name & $\mathrm{NDF}^{1,2}$ & $\mathrm{ADF}$ & $\mathrm{L} \mathrm{KMNO}_{4}$ & $\mathrm{H}_{2} \mathrm{SO}_{4}$ & $\mathbf{H}$ & C & $\mathrm{Si}$ \\
\hline & & $\%$ & $\%$ & $\%$ & $\%$ & $\%$ & $\%$ & \\
\hline Thalassia testudinum & Turtle grass & 59.4 & 40.4 & 22.9 & 9.1 & 19.0 & 17.5 & 0 \\
\hline Panicum maximum & Guinea & 79.9 & 52.1 & 8.4 & & 27.8 & 41.1 & 2.5 \\
\hline Cenchrus ciliaris & Buffel & 79.8 & 50.2 & 8.6 & & 29.6 & 36.7 & 3.6 \\
\hline Hemarthria altissima & Limpo & 78.8 & 43.6 & 9.5 & & 35.1 & 32.5 & 1.4 \\
\hline Brachiaria brizantha & Signal & 75.2 & 43.3 & 7.1 & & 31.8 & 33.7 & 2.4 \\
\hline Brachiaria ruziziensis & Congo & 74.9 & 43.6 & 7.5 & & 31.3 & 33.8 & 1.8 \\
\hline Digitaria valida & Giant Pangola & 74.1 & 45.1 & 7.4 & & 29.0 & 34.7 & 2.9 \\
\hline Hyparrhenia rufa & Jaraguá & 73.9 & 47.5 & 7.3 & & 26.4 & 35.7 & 4.3 \\
\hline Digitaria decumbens & Pangola & 72.8 & 44.9 & 7.6 & & 27.9 & 34.4 & 2.4 \\
\hline Pennisetum setosum & Venezuelan Elephant & 72.8 & 47.5 & 7.6 & & 25.2 & 34.4 & 2.3 \\
\hline Digitaria swazilandensis & African Crab & 71.9 & 41.3 & 6.3 & & 30.6 & 31.6 & 2.9 \\
\hline
\end{tabular}

${ }^{1}$ The fiber contents for the terrestrial grasses are taken from Coward-Lord et al. (12).

${ }^{2} \mathrm{NDF}$, neutral-detergent fiber; $\mathrm{ADF}$, acid-detergent fiber; $\mathrm{L}\left(\mathrm{KMnO}_{4}\right)$, lignin by potassium permanganate method; $\mathrm{L}\left(\mathrm{H}_{2} \mathrm{SO}_{4}\right)$, lignin by sulfuric acid method; $\mathrm{H}$, hemicellulose; C, cellulose; $\mathrm{Si}$, silica. 
or $\mathrm{H}_{2} \mathrm{SO}_{4}$ methods arise from the fate of cutin, which is largely retained in the $\mathrm{L}$ by the $\mathrm{H}_{2} \mathrm{SO}_{4}$ method and is excluded by the $\mathrm{KMnO}_{4}$ method. The $\mathrm{L}$ residue from the $\mathrm{H}_{2} \mathrm{SO}_{4}$ method has a higher carbon content than carefully prepared $\mathrm{L}$ and is undoubtedly degraded. As a result, there is ample evidence to support a higher true $\mathrm{L}$ figure than that which is obtained by the $72 \%$ sulfuric acid method. Polyphenolic and other unsaturated substances (tannins, pigments or proteins) that may not be completely removed in the $\mathrm{ADF}$, will react with $\mathrm{KMnO}_{4}$ and appear as $\mathrm{L}$. Van Soest and Robertson (49) determined that the accurate analyses for $\mathrm{L}$ require pre-extraction with neutral detergent, yielding much reduced crude $\mathrm{L}$ values. The comparative analysis with and without neutral detergent extraction is a rough analysis for tannin content.

The NDS fraction of the total leaf dry matter, which includes CP, lipids, soluble carbohydrates and ash, consisted of $40.6 \%$ in Thalassia. Among these components, perhaps the CP has the greatest significance, as it is converted at different trophic levels into the production of herbivores and carnivores. In this study, $17 \%(R=15.8-18.1 \%, n=6)$ of the total leaf dry matter in Thalassia testudinum consisted of CP (table 3). Other authors have determined the following percentages of $\mathrm{CP}$ in dried Thalassia leaves: 9-14.1\% (5), 13.1\% (9), 17\% (47), and 13.6-37.1\%, with an annual mean value of $25.7 \%$ (53).

On many occasions, Thalassia leaves have a higher or at least similar $\mathrm{CP}$ content than important forage plants. The mean CP content in ten tropical forage grasses harvested at different intervals ranged between 5.1 and $9.1 \%$ (13) (table 3). In a more recent study (27), 101 species of tropical grasses were analyzed chemically and the CP content ranged between 9.8 and $23.8 \%$, but only four genera averaged over $17 \%$. In a study of edible leaves of the tropics, Ruberté and Martin (43) tabulated the CP content of 25 plant species. Among the 25 species tested, the highest $\mathrm{CP}$ content was found to be $8.2 \%$ in cassava leaves (Manihot sp.). Among foodstuffs (53), 114 lines of corn contained between 9.8 and $16.3 \%$ CP (14), 49 varieties of grain sorghum contained between 8.6 and $16.5 \%$ (52), and wheat grain contained between 8.3 to $12.4 \%$; 11 ).

Essential nutritive minerals, such as $\mathrm{Ca}, \mathrm{P}, \mathrm{K}$ and $\mathrm{Mg}$, are found in considerable quantities in Thalassia leaves. These minerals are important in the diet of most animals, since they play crucial roles in the physiological processes for the maintenance, growth, reproduction, and milk or beef production of animal species. They participate in electrolytic balance, enzyme action, muscle irritability, as well as important structural components of bones and exoskeletons in many marine organisms $(2,8$, 45).

The mean percentage composition of these minerals in Thalassia leaves (table 3$)$ are the following: $\mathrm{Ca}, 1.32 \%(\mathrm{R}=1.21-1.47 \%, \mathrm{n}=6) ; \mathrm{P}$, 
TABLE 5.-Mineral composition and crude protein contents of Thalassia testudinum as compared to 10 tropical forage grasses

\begin{tabular}{|c|c|c|c|c|c|c|}
\hline Scientific name & Common name & $\mathrm{Ca}^{1}$ & $\mathrm{P}$ & $\mathrm{K}$ & $\mathrm{Mg}$ & $\mathrm{CP}^{2}$ \\
\hline & & $\%$ & $\%$ & $\%$ & $\%$ & $\%$ \\
\hline Thalassia testudinum & Turtle grass & 1.32 & .21 & 3.00 & 1.26 & 17.2 \\
\hline Panicum maximum & Guinea & .29 & .15 & 2.43 & .36 & 5.1 \\
\hline Cenchrus ciliaris & Buffel & .16 & .13 & 2.96 & .23 & 6.6 \\
\hline Hemarthria altissima & Limpo & .15 & .13 & 1.85 & .20 & 6.3 \\
\hline Brachiaria brizantha & Signal & .20 & .18 & 2.38 & .24 & 6.8 \\
\hline Brachiaria ruziziensis & Congo & .23 & .20 & 2.54 & .30 & 5.6 \\
\hline Digitaria valida & Giant Pangola & .18 & .14 & 2.50 & .32 & 7.5 \\
\hline Hyparrhenia rufa & Jaraguá & .33 & .17 & 1.94 & .28 & 6.6 \\
\hline Digitaria decumbens & Pangola & .25 & .19 & 1.66 & .23 & 7.2 \\
\hline Pennisetum setosum & Venezuelan Elephant & .20 & .17 & 3.03 & .30 & 7.7 \\
\hline Digitaria swazilandensis & African Crab & .22 & .19 & 2.57 & .27 & 9.1 \\
\hline
\end{tabular}

${ }^{1}$ The mineral contents for the terrestrial grasses are taken from Arroyo-Aguilu and Coward-Lord (2).

${ }^{2}$ The protein content for the terrestrial grasses are taken from Coward-Lord et al. (13). 
$.21 \%(\mathrm{R}=.19-.23 \%, \mathrm{n}=6) ; \mathrm{K}, 3.0 \%(\mathrm{R}=2.47-3.30 \%, \mathrm{n}=6) ;$ and $\mathrm{Mg}$, $1.26 \%(\mathrm{R}=1.09-1.38 \%, \mathrm{n}=6)$. Schroeder (44) found similar values for $\mathrm{Mg}$ content $(1.1 \% \pm .1, \mathrm{n}=4)$ and higher values for Ca content $(2.7 \% \pm$ $1.7, \mathrm{n}=4$ ) in Thalassia leaves collected on the west coast of Puerto Rico. Walsh and Grow (53) found a Mg concentration peak between 1.20-1.25\% and a $\mathrm{K}$ maximum around $2.45 \%$ in Thalassia leaves. These mineral contents in Thalassia leaves are comparatively higher than those obtained in tropical forage grasses (2) (table 3) and are much higher than 15 species of edible leaves tabulated in the report of Ruberté and Martin (43).

The chemical components of Thalassia leaves, therefore, provide the seagrass community with a nutrient-rich food supply which supports upper trophic levels in this ecosystem type. Thalassia leaves can also enrich other marine biotopes by physical or biological export. Biological transport of Thalassia matter to coral reefs, for example, occurs by the migration of several fish and urchins that feed on Thalassia and then migrate to coral reefs for shelter. Fecal material of these herbivores deposited on the reefs may constitute a significant nutrient and energy import to the coral reef community $(29,35,36,40)$.

At the present time, the utilization of seagrasses as food by animals, particularly those of economic importance to man, is negligible. Although Thalassia testudinum and Ruppia maritima have been used successfully in preliminary experiments as fertilizers for tomatoes (48) and as feed supplement for sheep (5), studies have not continued along these lines. Thalassia beds are considered among the most productive biological systems in the world. However, only a small fraction of the production of seagrasses and their associated algae are being utilized directly by man. For obtaining increased benefits in seagrass production, there is a need for the preservation of Thalassia beds; for the restoration of Thalassia beds and its transplantation into bare, marine substrates; for the restoration of queen conch (Strombus gigas) and green turtle (Chelonia mydas) populations; and for the consideration of seagrasses in the feeding of domestic animals.

\section{RESUMEN}

Se describe la composición química de las hojas de Thalassia. Del total de materia seca, $40.6 \%$ consiste de proteínas, lípidos, hidratos de carbono solubles y ceniza. El contenido en proteína bruta consiste de $17 \%(R=15.8-18.1 \%)$. Los minerales nutritivos esenciales se encontraron en cantidades considerables: calcio, $1.32 \%(R=1.21-1.47 \%)$; fósforo, $.21 \%(R=.19-.23 \%)$; potasio, $3.0 \%(R=2.47-3.30 \%)$ y magnesio, $1.26 \%(R=1.09-1.38 \%)$. Los componentes de la membrana celular fueron $59.4 \%(R=46.1-64.6 \%)$, del cual $19.1 \%$ consiste de 
hemicelulosa. El valor porcentual de lignina varía, dependiendo de si $\mathrm{KMnO}_{4}$ ó $\mathrm{H}_{2} \mathrm{SO}_{4}$ se usa como agente oxidante: $22.9 \%\left(\mathrm{KMnO}_{4}\right)$ ó $9.1 \%$ $\left(\mathrm{H}_{2} \mathrm{SO}_{4}\right)$. Se postulan en este trabajo cinco cadenas alimenticias básicas para describir la importancia de las hojas de Thalassia en la producción de organismos marinos: cadena alimenticia de herbivoros grandes, cadena alimenticia de peces herbívoros, cadena alimenticia de gasterópodos herbívoros y la cadena alimentica detrítica. Se evaluó el valor potencial de Thalassia como fuente de alimento para animales domésticos.

\section{LITERATURE CITED}

1. Allain, J. Y., 1975. Mortalidad natural de Lytechinus variegatus (Lamarck), (Echinodermata-Echinoidea), en la bahía de Cartagena, Colombia, Museo del Mar, No. 7, Fundación Univ. de Bogotá Jorge Tadeo Lozano 51-60.

2. Arroyo-Aguilú, J. A. and Coward-Lord, J., 1974. Mineral composition of 10 tropical grasses in Puerto Rico, J. Agri. Univ. P.R. 59 (4): 426-36.

3. - and - 1974. Relationships between and within physical and chemical constituents and in vitro true digestibility in tropical forages, J. Agri. Univ. P.R. 58 (4): $437-$ 47.

4. Association of Official Analytical Chemists, 1975. Official Methods of Analysis, 12th ed, Washington, D.C.

5. Bauersfeld, P., Kifer, R. R., Durrant, N. W., and Sykes, J. E., 1969. Nutrient content of turtle grass (Thalassia testudinum). Proc. Intl. Seaweed Symp. 6: 637-45.

6. Brook, I. M., 1977. Trophic relationships in a seagrass community (Thalassia testudinum), in Card Sound, Florida. Fish diets in relation to macrobenthic and cryptic faunal abundance, Trans. Am. Fish. Soc. 106 (3): 219-29.

7. Brownell, W. N., 1977. Reproduction, laboratory culture, and growth of Strombus gigas and Strombus pugilus in Los Roques, Venezuela, Bull. Mar. Sci. 27 (4): 668-80.

8. Buck, G. R. and Griefe, D. G., 1973. Minerals for dairy cattle, Ont. Minist. Agri. Food Factsheet, AGDEX 410/65.

9. Burkholder, P. R. and Burkholder, L. M., 1959. Some chemical constituents of turtle grass Thalassia testudinum, Bull. Torr. Bot. Club 86: 88-93.

10. Camp, D. K., Cobb, S. P., and Van Breedveld, J. F., 1973. Overgrazing of seagrasses by a regular urchin, Lytechinus variegatus, BioScience 23: 37-8.

11. Chrominski, A., 1967. Effect of (2-chloroethyl) trimethylammonium chloride on protein content, protein yield, and some qualitative indexes of winter wheat grain, J. Agri. Food Chem. 15: 109-12.

12. Coward-Lord, J., Arroyo-Aguilú, J. A., and Garcia-Molinari, O., 1974. Fibrous carbohydrate fractions and in vitro true and apparent digestility of 10 tropical forage grasses, J. Agri. Univ. P.R. 58 (3): 293-304.

13.,-- , and,- 1974 . Proximate nutrient composition of 10 tropical forage grasses, J. Agri. Univ. P.R. 58 (3): 305-11.

14. Davis, L. W., Williams, Jr., W. P., and Crook, L., 1970. Interrelationships of the protein and amino acid contents of inbred lines of corn, J. Agri. Food Chem. 18: 357-60.

15. den Hartog, C., 1977. Structure, function, and classification in seagrass communities, In Seagrass Ecosystems, McRoy, C. P. and Helfferich, C., Ed, Marcel Dekker Inc., New York and Basel, 4: 89-119.

16. Glynn, P. W., 1964. Common marine invertebrate animals of the shallow waters of Puerto Rico, In Historia Natural de Puerto Rico. Univ. of P.R., Mayagüez, P.R.

17. Goering, H. K., and Van Soest, P. J., 1970. Forage fiber analysis (apparatus, reagents, procedures, and some applications), USDA Agri. Handbook. 
18. Greenway, M., 1976. The grazing of Thalassia testudinum in Kingston Harbour, Jamaica. Aquatic Bot. 2: 117-26.

19. Greweling, T., 1962. An extraction procedure for the determination of total calcium, magnesium, and potassium in plant tissue, J. Agri. Food Chem. 10: 138-40.

20. Gunter, G., 1962. Shrimp landings and production of the state of Texas for the period 1956-1959, with a comparison of other Gulf States, Tex. Univ. Inst. Mar. Sci. Pub. 8: $216-26$.

21. Heck, K. L., 1977. Comparative species, richness, composition, and abundance of invertebrates in Caribbean seagrass (Thalassis testudinum) meadows (Panamá), Mar. Biol. 41: 335-48.

22. Hirth, H. F., 1971. Synopsis of biological data on the green turtle Chelonia mydas (Linnaeus), FAO Fisheries Synopsis No. 85: 14-31.

23. Hoese, H. D. and Jones, R. S., 1963. Seasonality of larger animals in a Texas turtle grass community, Univ. Tex. Inst. Mar. Sci. Pub. 9: 37-47.

24. Ingle, R. M. and Smith, F. G. W., 1949. Sea turtles and the turtle industry of the West Indies, Florida, and the Gulf of Mexico, with annotated bibliography, In special publication of the Marine Laboratory. Coral Gables, Univ. Miami, Miami, Fla.

25. Jackson, J. B. C., 1972. The ecology of the molluses of Thalassia communities, Jamaica, West Indies. II, Molluscan population variability along an environmental stress gradient, Mar. Biol. 14 (7): 304-37.

26. ——, 1973. The ecology of molluses of Thalassia communities, Jamaica, West Indies. I. Distribution, environmental physiology, and ecology of common shallow-water species, Bull. Mar. Sci. 23 (2): 313-50.

27. Kayongo-Male, H., Thomas, J. N., Ullrey, D. E., Deans, R. J., and Arroyo-Aguilú, J. A., 1976. Chemical composition and digestibility of tropical grasses, J. Agri. Univ. P.R. 60 (2): $186-200$.

28. Kier, P. M. and Grant, R. E., 1965. Echinoid distribution and habits, Key Largo Coral Reef Preserve, Florida, Smithson. Misc. Collect., 149 (6): 1-68.

29. Kikuchi, T. and Perés, J. M., 1977. Consumer ecology of seagrass beds, In: Seagrass Ecosystems, McRoy, C. P., and Helfferich, C., Ed, Marcel Dekker, Inc., New York and Basel 4: 147-85.

30. Lawrence, J. M., 1975. On the relationships between marine plants and sea urchins, Oceanogr. Mar. Biol. Ann. Rev, 13: 213-86.

31. Lewis, J. B., 1958. The biology of the tropical sea urchin Tripneustes esculentus Leske in Barbados, British West Indies, Can. J. Zool. 36: 607-21.

32. McRoy, C. P. and Helfferich, C., 1977. Preface, In Seagrass Ecosystems, McRoy, C. P., and Helfferich, C., Ed, Marcel Dekker, Inc., New York and Basel 4: 111.

33. Moore, H. B. and McPherson, B. F., 1965. A contribution to the study of the productivity of the urchins Tripneustes esculentus and Lytechinus variegatus, Bull. Mar. Sci. 15 (4): 855-71.

34. Odum, H. T., 1974. Tropical marine meadows; In Coastal Ecological Systems of the United States, Odum, H. T., Copeland, B. J., McMahan, E. A., Ed, The Conservation Foundation, Washington, D.C., 1: 441-87.

35. Ogden, J. C., Helm, D., Peterson, J., Smith, A., and Weisman, S., 1972. An ecological study of Tague Bay reef, St. Croix, U. S. Virgin Islands, West Indies Lab., Fairleigh Dickinson Univ., Spec. Pub. 1.

36. - - Brown, R. A., and Salesky, N., 1973. Grazing by the echinoid Diadema antillarum Phillippi: Formation of halos around West Indian patch reefs, Sci. 182: 715-7.

37. Phillips, R. C., 1960. Observations on the ecology and distribution of the Florida seagrasses, Fla. State Board Cons. Prof. Pap. Serv. 2: 1-71.

38. Prim, P. P., 1973. M. S. thesis, Univ. South. Fla, Tampa, Fla.

39. Randall, J. E., 1964. Contributions to the biology of the queen conch, Strombus gigas, 
Bull. Mar. Sci. Gulf and Carib., 14: 246-95.

40. ——, 1965. Grazing effect on seagrass by herbivorous reef fishes in the West Indies, Ecology, 46: 255-60.

41. _ - 1967. Food habits of reef fishes of the West Indies, Studies in Trop. Ocean. 5: 665847.

42. Riera, A., 1955. The method of foliar diagnosis as applied to sugar cane, II. The chemical analysis of sugar cane leaf samples, Agri. Exp. Stn. Univ. P.R. Bull. 123.

43. Ruverté, R. M. and Martin, F. W., 1975. Hojas comestibles del trópico. Printed by Antillean College Press, Mayagüez, P.R.

44. Schroeder, P. B., 1975. Thermal stress in Thalassia testudinum. Ph.D. dissertation, Univ. Miami, Coral Gables, Fla., 113 pp.

45. Sullivan, J. T., 1969. Chemical composition of forages with reference to the needs of the grazing animal, A review of recent research findings, ARS 34-107, USDA.

46. Thayer, G. W., Wolfe, D. A., and Williams, R. B., 1975. The impact of man on seagrass systems, Am. Sci., 63: 188-96.

47. Thorhaug, A., Seagar, D., and Roessler, M. A., 1973. Impact of a power plant on a subtropical estuarine environment, Mar. Poll. Bull. 7 (11): 166-9.

48. Van Breedveld, J. F,, 1966. Preliminary study of seagrass as a potential source of fertilizer, Fla. State Board Conserv. Mar. Lab. Spec. Sci. Rep. 9: 1-20.

49. Van Soest, P. J. and Robertson, J. B., 1976. Composition and nutritive value of uncommon feedstuffs, Proc. Cornell Nutr. Conf. Feed Manuf. 102-11.

50. - - and Wine, R. H., 1968. Determination of lignin and cellulose in acid-detergent fiber with permanganate. J. Assoc. Off. Anal. Chem. 51: 780-5.

51. Vincente, V.P. and Rivera, J. A. Depth limits of the seagrass Thalassia testudinum (König) in Jobos and Guayanilla Bays, Puerto Rico. Carib. J. Sci. 17. (In press).

52. Virupaksha, T. K. and Sastry, L. V. S., 1968. Studies on the protein content and amino acid composition of some varieties of grain sorghum. J. Agri. Food Chem. 16: 199203.

53. Walsh, G. E. and Grow, T. E., 1973. Composition of Thalassia testudinum and Ruppia maritima, Quart. J. Fla. Acad. Sci. 35 (2): 97-108.

54. Zieman, J. C., 1975. Quantitative and dynamic aspects of the ecology of turtle grass, Thalassia testudinum. In: Estuarine Research, Cronin, L. E., Ed, Acad. Press, New York, pp. 541-62. 